Int. J. Dev. Biol. 58: 127-137 (2014)

doi: $10.1387 / \mathrm{ijdb} .130340 \mathrm{pd}$

\title{
Transcriptomics of the human endometrium
}

\author{
PATRICIA DÍAZ-GIMENO1* , MARIA RUÍZ-ALONSO2, DAVID BLESA ${ }^{1,2}$ and CARLOS SIMÓN 1,2,3
}

${ }^{1}$ Fundación Instituto Valenciano de Infertilidad (FIVI), Valencia University and Instituto Universitario IVI/INCLIVA, Spain, ${ }^{2}$ IVIOMICS, Parc Cientific Valencia University, Paterna, Valencia, Spain and ${ }^{3}$ Department of Ob/Gyn, Stanford University School of Medicine, Stanford University, CA, USA

\begin{abstract}
During the mid-secretory phase, the endometrium acquires the receptive phenotype, which corresponds to the only period throughout the endometrial cycle in which embryo implantation is viable. Endometrial receptivity is a crucial process and even more important in Assisted ReproductiveTechnologies (ART) where embryo-endometrial synchronization is coordinated through embryo transfer timing. Over the last decade, transcriptomic analyses performed on the human endometrium have shown that specific genomic signatures can be used to successfully phenotype different phases of the menstrual cycle including the receptive stage, independently of the histological appereance of the endometrial tissue. In this paper, we review current evidence demonstrating that endometrial transcriptomics objectively identifies the implantation window in a personalized manner, opening the field for the diagnosis of the endometrial factor in ART and moving to stratified medicine at this level, using microarray technology and soon high-throughput next generation sequencing coupled with functional and systems genomics approach.
\end{abstract}

KEY WORDS: Endometrial Receptivity Array, personalised embryo transfer, personalised window of implantation, clinical translation, systems biology

\section{Introduction}

The human endometrium is a dynamic organ that undergoes cyclic changes in response to ovarian steroids, cytokines and chemokines (Wilcox et al., 1999; Lessey 2000; Salamonsen et al., 2007). In mamals, its main function is to allow the adhesion and invasion of the blastocyst in order to initiate successful placentation and pregnancy. In humans and primates, the endometrium is nonreceptive to embryos for most of the menstrual cycle, but becomes receptive during a spatially and temporally restricted period during the secretory phase known as the window of implantation (WOI) (Harper 1992; Giudice 1999), which is regulated by the presence of exogenous or endogenous progesterone $(P)$ after previous estradiol (E2) stimulation (Finn and Martin 1974; Martín et al., 2002).

From anatomical medicine, with its use of histological dating methods (Noyes et al., 1950, 1975), to the new '-omics' technologies, great effort has been put into understanding and characterising how endometrial receptivity functions, and how it can be used as a guide for diagnosing the endometrial factor in assited reproductive technologies (ART). Despite the historical relevance of traditional endometrial dating criteria, its accuracy, reproducibility, and functional relevance has been questioned in randomised studies (Coutifaris et al., 2004; Murray et al., 2004). However, the research effort and application of classical molecular technologies to objectively diagnose endometrial receptivity still remains insufficient (Lessey, 2011), especially given that it is obvious that it is a complex and multifactorial process. Therefore, we postulated that the application of an '-omics' approach might enable endometrial biomarker research and hold the key to its clinical application (Diaz-Gimeno et al., 2011, 2013; Berlanga et al., 2011; Altmäe et al., 2012; Garrido-Gomez et al., 2013; Ruíz-Alonso et al., 2013; and recently reviewed by Altmäe et al., 2013).

Twenty-first century biology is the era of '-omics' (Quackenbush, 2006), which refers to high-throughput techniques and massive data analysis, allowing molecular profiling and changes between groups or individuals to be investigated. The study of genomes and the complete collection of genes that they contain (genomics), epigenetic DNA modifications (epigenomics), gene expression or

\footnotetext{
Abbreviations used in this paper: ART, assisted reproductive technologies; COS, controlled ovarian stimulated; E2, estradiol; ERA, endometrial receptivity array; FDA, Food and Drug Administration; GSEA, gene set enrichment analysis; HRT, hormonal replacement therapy; IVF, in vitro fertilization; MAQC, microarray quality control; MIAME, minimum information about a microarray experiment; NGS, next generation sequencing; $\mathrm{P}$, progesterone; $\mathrm{P}+$, progesterone + days; $\mathrm{PCA}$, principal component analysis; pET, personalised embryo transfer; RIF, recurrent implantation failure; RNA-seq, RNA sequencing; WOI, window of implantation.
}

\footnotetext{
*Address correspondence to: Patricia Díaz-Gimeno. C/ Catedrático Agustín Escardino, 9. Paterna (Valencia) 46980, Spain.
} Tel: +34-963-90-33-05. Fax: +34-963-90-25-22. E-mail: patricia.diaz@ivi.es 
transcriptome profiling (transcriptomics), the presence and quantification of proteins i.e. the proteome (proteomics), or the composition and abundance of metabolites i.e. the metabolome (metabolomics), are examples of the different '-omic' approaches used to analyse biological samples in a physiological context. '-Omics' includes holistic perspectives that are being applied to create new types of biological data such as lipidomics (collection of lipids, i.e. the lipidome), secretomics (secreted proteins, i.e. the secretome), interactomics (the interactome, or a 'systems biology' approach) and a big list of derived '-omics' fields that consider other groups and subgroups of biological molecules and processes (omics.org http://omics.org/index.php/Omics_classification).

Personalised medicine uses genetic, or any other biomarker information, such as molecular profiles, along with it diagnostic, prognostic, and therapeutic strategies precisely tailored to each patient's requirements, including which therapies and what doses are required for an optimal outcome. The terms genetic, personalised, stratified, or precision medicine, pharmacogenetics and pharmacogenomics have all been used interchangeably to mean "the study of genetic variations and their influence on the way people respond to medications" (Mirnezami et al., 2012; the Food and Drug Administration (FDA) organisation website http://www. fda.gov/Drugs/NewsEvents/ucm325475.htm)

In the last decade, a total of 269 relevant manuscripts have been published about '-omics' studies in the human endometrium. 164 of them (61\%) were transcriptomic publications (for a review see Altmäe et al., 2013, Fig. 1). Accumulated clinical evidence indicates that transcriptomics, based on microarray technology, is now the most mature and stable technology available for implementing personalised diagnosis of the endometrial factor in reproductive medicine.

At a general level, transcriptomic and bioinformatic analyses are standardised and normalised (Brazma et al., 2001; MAQC consortium 2006, 2010). Gene expression profiling has been used for tumor classification (Quackenbush, 2006), and machine-learning algorithms have been implemented as predictive models for the microarray signatures (Medina et al., 2007) used in diagnostic and prognostic prediction (Simon, 2003). The FDA has already approved the Agendia MammaPrint microarray as a diagnostic test for the assessment and prognosis prediction of distant metastasis in patients with breast cancer (van't Veer et al., 2002). Following this line, the Endometrial Receptivity Array (ERA) test is a microarray-based machine-learning predictive model used to diagnose human endometrial receptivity status (Díaz-Gimeno et al., 2011, 2013), guiding personalised embryo transfer (Ruiz-Alonso et. al., 2013).

The aim of this manuscript is to review the use of transcriptomics in the human endometrium and its potential to be used as an objective tool to diagnose endometrial receptivity status and therefore to personalise embryo transfer according to endometrial status.

\section{Transcriptomics}

Transcriptomics attempts to analyse patterns of gene expression and to correlate them with their underlying biology. DNA microarray analysis was implemented to measure the expression of thousands of genes simultaneously and was quickly adopted by the scientific community for the study of a wide range of biological processes. Most of the early studies had a simple and powerful design: to compare two biological classes in order to identify the differential expression pattern between them. Genes with potential relevance to a wide range of biological processes, such as the progression of cancer, the causes of asthma, heart disease, and neuropsychiatric disorders, or factors associated with infertility have been identified and analysed (Schena, 1995; Quackenbush, 2006). Gene expression arrays are the ideal technology to analyse the levels of transcription in tissues, assessing functions that might be reversibly changeable.

Transcriptomics also allows gene expression characterisation at the mRNA level of a population, giving rise to a sample-specific molecular profile. This fact led to a new biomarker concept, that of transcriptomic signatures that define a biological process or disease, and thus represent new opportunities to characterise function or disease phenotypes (Nevins and Potti, 2007).

Several consortiums have produced guidelines on the quality of microarray analyses. Minimum information about a microarray experiment (MIAME) helps to increase the underlying standard of microarray data (Brazma et al., 2001) and establish the basis of microarray procedures. The microarray quality control (MAQC)
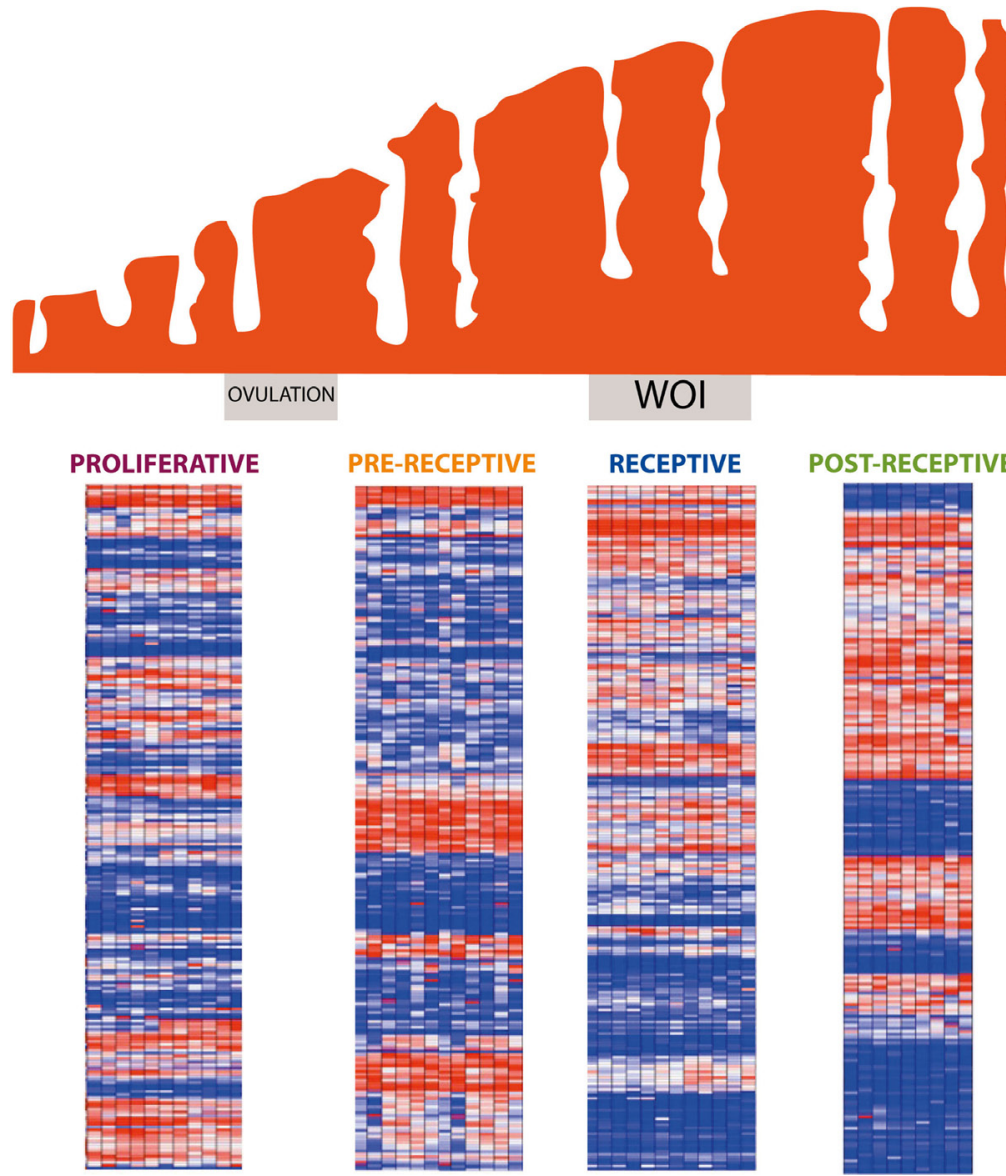

Fig. 1. Endometrial transcriptomics profile. Evolution of endometrial tissue over time and the gene expression profile at each given stage. Heatmap showing the Endometrial Receptivity Array (ERA) gene expression profiles in each endometrial cycle stage (proliferative, pre-receptive, receptive, and post-receptive). 
phase I (MAQC Consortium, 2006) focused on the technical aspects of gene expression measurements and robust technology platforms. For clinical predictive phenotypes an additional requirement is the development of accurate and reproducible multivariate expressionbased gene prediction models, also referred to as 'classifiers'. The second MAQC phase focused on these predictive models to establish a summary of observations and recommendations that could be used to develop and validate microarray-based predictive models. These are increasingly submitted by the industry to the FDA to support medical product development and testing applications (MAQC Consortium, 2010). In addition, the EMERALD project, based on MIAME standards, provides quality guidelines for further model validations and details about practical clinical applications for microarray data (Beisvag et al., 2011).

An appropriate and reproducible protocol is needed in order to use any technology in a clinical setting, and so quality control and enabling data sharing, therefore the possibility of reanalysis and comparison is critical. All these studies and standardised microarray data analysis methods help to guarantee the efficacy of the clinical applicability of transcriptomics to phenotype diseases, and thereafter their application to precision medicine.

\section{Transcriptomics, functional analysis and the systems biology approach}

To analyse transcriptomic profiles or signatures, exploratory methods and statistical tests are used. Exploratory methods such as trees, clustering, or principal component analysis (PCA) are used to discover the behavior of the profiling sample and its variability within the microarray data cohort. There are several different user-friendly software platforms available, such as the online Babelomicsplatform (Medina et al., 2010; http://babelomics. bioinfo.cipf.es/), which make microarray data to analysis easy, by using visual heatmap representations to show differential expression patterns between different scenarios, genes, and samples.

Transcriptomics describes gene activity; therefore concurrent functional analysis is the key to understanding the underlying biology. Early functional analysis involved mapping expressed genes onto pathway maps such as the Kyoto encyclopedia of genes and genomes (KEGG pathways; Kanehisa and Goto, 2000) or functional ontologies such as gene ontology (GO; Ashburner, 2000). Nowadays, functional analysis has developed a new perspective, based on systems biology which considers the functional interdependency of the molecular components of human cells; therefore a disease is rarely a consequence of a single gene abnormality. Functional analysis involves genes in the genomic and cellular context and has recently expanded into three main approaches: functional enrichment analysis that highlights and ranks biologically relevant pathways, processes, disease markers, or other functionality in a gene list (Subramanian, 2005), biological network reconstruction, and interactome analysis (Vidal et al., 2011).

Gene set enrichment analysis (GSEA), using a systems biology approach, analyses functions by considering genes either in a genomic or cellular context. The genes are ranked by any biological criteria (e.g. differential expression between experimental cohorts and healthy controls) and the algorithm searches for blocks of functionally-related genes without imposing any artificial thresholds (e.g FatiScanfrom Babelomics; for a tutorial see: http://bioinfo.cipf. es/babelomicstutorial/gene_set_analysis).

Network science models complexity by 'simplifying' complex systems into components (nodes: molecules) and interactions (edges) based on different biological parameters, and applies graph theory to generate systems properties (centrality, betweenness, the shortest paths etc. Vidal et al., 2011). Depending on the relationship between these nodes, different types of networks emerge, e.g. metabolic, protein-protein interaction, gene regulatory, or interactome networks which integrate with other cellular networks such as the transcriptional profiling, phenotypic profiling, or genetic interaction networks (Vidal et al., 2011).

In transcriptional profiling networks, nodes represent genes, and edges link pairs of genes that show co-expression above a set threshold. Common signalling cascades of gene products or protein complexes that function together are expected to show more similarities in their expression behavior than random sets of gene products (Stuart et al., 2003).

\section{Transcriptomics prediction}

Predictors are used to classify new microarray data into specific classes (e.g. disease case samples or healthy controls) based on criteria previously constructed with a model dataset which contains the classes with which the samples will be phenotyped. This dataset is named the training set. The underlying predictor strategy is as follows: if the differences between the classes are as a consequence of measureable differences in gene expression levels, these differences can be identified and used to assign the classes for a new microarray profiling set.

Microarray data works well with several classification algorithms recommended by MAQC phase II (MAQC Consortium, 2010). The best algorithms for classifying microarray data are support vector machines, nearest neighbour, and random forest. The possibility of classification using transcriptomic profile data is a powerful tool in clinical applications and in personalised medicine, and is independent of the specific functional meaning of the transcriptomic signature (Shi et al., 2010).

\section{Transcriptomics of human endometrium}

Evidence accumulated over the last decade (Table 1, for a review see Ruiz-Alonso et al., 2012; Garrido-Gomez et al., 2013; Altmäe et al., 2013) indicates that human endometrial transcriptomics is reaching maturity. Different areas have been investigated, such as the transcriptomic expression throughout the menstrual cycle (for reviews see Horcajadas et al., 2004; Giudice 2006; Horcajadas et al., 2007; Aghajanova et al., 2008 a, b; Haouzi et al., 2012; Ruiz-Alonso et al., 2012; Garrido-Gomez et al., 2013), endometrial transcriptomics during different treatment protocols (reviewed in Martinez-Conejero et al., 2007; Ruiz-Alonso et al., 2012), endometriosis (reviewed in Matsuzaki, 2011), and endometrial cancer (reviewed in Doll et al., 2008). The perceived limitations of this technology lie in the differences in experimental design, timing, the conditions of endometrial sampling, sample selection criteria, annotation versions used, pipelines for data processing, and the absence of consistent standards for data presentation (Horcajadas et al., 2007; Ruiz-Alonso et al., 2012; Ulbrich et al., 2013). These different factors have made performing meta-analyses of similar studies on specific stages of endometrial development nearly impossible (Ulbrich et al., 2013). Additionaly, the powerful value of transcriptomic data in pathologies such as endometriosis has been limited by the absence of uniformity in the validation of these 
cumulative data. Multiple comparisons have been made, revealing distinct transcriptomic differences in a variety of biological processes and signalling pathways unique to ectopic versus eutopic endometrium (as is reviewed in Altmäe et al., 2013). However, clinically meaningfull biomarkers for the pathophysiology and/or aetiology of endometriosis are still to be identified (Matsuzaki 2011; Fassbender et al., 2013).

Also different endometrial cellular compartments have been analysed, demonstrating specific cell-type gene expression profiles (Yanaihara et al., 2005; Evans et al., 2012; Ulbrich et al., 2013). In all of these studies stromal and epithelial fractions were isolated by laser capture microdissection, and the mRNA signatures were related to the menstrual cycle day (Yanaihara et al., 2005; Evans et al., 2012). In addition, Evans' group compared Affymetrix and Agilent microarray platforms, demonstrating concordance in their results (Evans et al., 2012). An alternative approach to laser dissection for isolating tissues is fluorescence-activated cell sorting, which has also been used to demonstrate cell-type specific gene expression (Spitzer et al., 2012). However, the majority of transcriptomic studies have used random biopsies of endometrial tissue which contain all cell types. The transcriptomic profile of the diferent phases of the menstrual cycle is visualised using heatmaps (see Fig 1).

\section{Transcriptomics of endometrial receptivity}

'Endometrial receptivity' describes the phenotype which allows embryo adhesion and placentation to occur. This concept was first suggested in the 1970s (Croxatto et al., 1978), but it was the pioneering work of Wilcox et al., that initiated the field, demonstrating that in most successful pregnancies the "conceptus" implants 8 to 10 days after ovulation (Wilcox et al., 1999). Historically, it has always been accepted that the WOI is constant, always permitting embryo implantation, and so personalisation was never considered, especially because the objective diagnosis of the endometrial factor and therefore the WOI did not previously exist. Based on these grounds, an important scientific and clinical objective has been to find a molecular signature which characterises receptive endometrium in order to gain an objective insight into this crucial function (reviewed in Ruiz-Alonso et al., 2012).

Endometrial receptivity is the result of the synchronised and integrated interaction of ovarian hormones, growth factors, lipid

TABLE 1

\section{ORIGINAL PAPERS ON ENDOMETRIAL TRANSCRIPTOMICS IN ASSISTED REPRODUCTIVE MEDICINE}

\begin{tabular}{|c|c|c|c|c|}
\hline Authors & Date & Time of Biopsy & Comparative & Array \\
\hline Carson et al & 2002 & $\mathrm{LH}+(2-4)$ vs $\mathrm{LH}+(7-9)$ & ES vs MS & HG U95A (Affymetrix) \\
\hline Kao et al & 2002 & CD 8-10 vs $\mathrm{LH}+(8-10)$ & LP vs MS & HG U95A (Affymetrix) \\
\hline Borthwick et al & 2003 & CD 9-11 vs $\mathrm{LH}+(6-8)$ & LP vs MS & HG U95A-E (Affymetrix) \\
\hline Riesewijck et al & 2003 & $\mathrm{LH}+2$ vs $\mathrm{LH}+7$ & ES vs MS & HG U95A (Affymetrix) \\
\hline Mirkin et al & 2004 & $\mathrm{LH}+8$ vs $\mathrm{hCG}+9$ & Ag vs Atg vs NC & HG U95Av2 (Affymetrix) \\
\hline Ponnampalam et al & 2004 & Complete cycle, dating by Noyes & EP vs MP vs LP vs ES vs MS vs LS vs $M$ & Homemade (Peter MacCallum Cancer Institute) \\
\hline Horcajadas et al & 2005 & $\mathrm{LH}(+2 ;+7)$ vs hCG +7 & $\mathrm{NC}$ vs $\mathrm{COH}$ & HG U133A (Affymetrix) \\
\hline Mirkin et al & 2005 & $\mathrm{LH}+3$ vs $\mathrm{LH}+8$ & ES vs MS & HG U95Av2 (Affymetrix) \\
\hline Punyadeera et al & 2005 & CD $2-5$ vs CD 11-14 & M vs LP & HG U133A (Affymetrix) \\
\hline Simon et al & 2005 & LH $(+2 ;+7)$ vs hCG $(+2 ;+7)$ & Ag vs Atg vs NC & HG U133A (Affymetrix) \\
\hline Yanahaira et al & 2005 & CD 9-11 & Epithelial vs Stromal cells in Proliferative phase & BD Atlas Nylon cDNA Expression Array; BD Biosciences (Clontech) \\
\hline Critchley et al & 2006 & Dating by Noyes & MS vs LS & HG U133A (Affymetrix) \\
\hline Talbi et al & 2006 & Complete cycle, dating by Noyes & EP vs MP vs LP vs ES vs MS vs LS & HG U133 Plus 2.0 (Affymetrix) \\
\hline Horcajadas et al & 2008 & $\mathrm{LH}+(1-9)$ vs hCG $+(1-9)$ & NC vs COS & HG U133A (Affymetrix) \\
\hline Liu et al & 2008 & $\mathrm{LH}+7$ vs hCG+7 & NC vs COS & HG U133A (Affymetrix) \\
\hline Macklon et al & 2008 & $\mathrm{LH}+5$ vs $\mathrm{hCG}+2$ & NC vs COS & HG U133 Plus 2.0 (Affymetrix) \\
\hline Haouzi et al & $2009 b$ & $\mathrm{LH}(+2 ;+7)$ vs hCG $+(+2 ;+5)$ & NC vs COS & HG U133 Plus 2.0 (Affymetrix) \\
\hline Haouzi et al & $2009 a$ & $\mathrm{LH}+2$ vs $\mathrm{LH}+7$ & ES vs MS & HG U133 Plus 2.0 (Affymetrix) \\
\hline Koler et al & 2009 & CD 21 & Fertility vs Infertility & Array-Ready Oligo Set for the Human Genome Version 3.0 (Operon) \\
\hline Altmae et al & 2010 & $\mathrm{LH}+7$ & Fertility vs Infertility & Whole Human Genome Oligo Microarray (Agilent Technologies), \\
\hline Haouzi et al & 2010 & LH $(+2 ;+7)$ vs hCG $(+2 ;+5)$ & Ag vs Atg vs NC & HG U133 Plus 2.0 (Affymetrix) \\
\hline Tseng et al & 2010 & Dating by Noyes & ES vs MS vs LS & HG U133 Plus 2.0 (Affymetrix) \\
\hline Van Vaerenbergh et al & 2010 & $\mathrm{LH}+(5-7)$ & MS vs Pregnant & HG U133 Plus 2.0 (Affymetrix) \\
\hline Blockeel et al & 2011 & Oocyte retrieval & rFSH vs low-dose hCG & HG U133 Plus 2.0 (Affymetrix) \\
\hline Diaz-Gimeno et al & 2011 & $\begin{array}{l}(\mathrm{LH}+1,+3,+5 \text { vs } \mathrm{LH}+7)(\mathrm{LH}+(1-5) \\
\text { vs } \mathrm{LH}+7 \text { vs } \mathrm{CD} 8-12)\end{array}$ & LP vs ES vs MS & HG U133A (Affymetrix) and Homemade "ERA" \\
\hline Labarta et al & 2011 & $\mathrm{rCG}+7$ & Different serum progesterone level & Whole Human Genome Oligo Microarray (Agilent Technologies), \\
\hline Van Vaerenbergh et al & 2011 & Oocyte retrieval & Different serum progesterone level & HG U133 Plus 2.0 (Affymetrix) \\
\hline Evans et al & 2012 & $\mathrm{LH}+2$ vs $\mathrm{LH}+7$ & Epithelial vs Stromal cells in Proliferative phase & Agilent 4x44K; HG U133 Plus 2.0 (Affymetrix) \\
\hline Petracco et al & 2012 & CD 1-3 vs CD 5-8 vs CD 11-13 & EP vs MP vs LP & $\begin{array}{l}\text { GeneChip Human Gene } 1.0 \mathrm{ST} \\
\text { Array (Affymetrix) }\end{array}$ \\
\hline Díaz-Gimeno et al & 2013 & Dating by Noyes vs ERA prediction & MP vs ES vs MS vs LS & Homemade "ERA" \\
\hline Ruiz-Alonso et al & 2013 & $\mathrm{P}+5 / \mathrm{LH}+7$ RIF vs Controls & pWOI/pWOIdelayed/pWOladvanced & Homemade "ERA" \\
\hline Bermejo et al & 2013 & Oocyte retrieval COS & Comparing $4 \mathrm{GnRH}$-a protocols & Homemade "ERA" \\
\hline
\end{tabular}

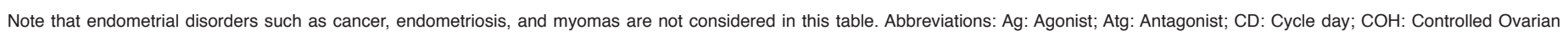

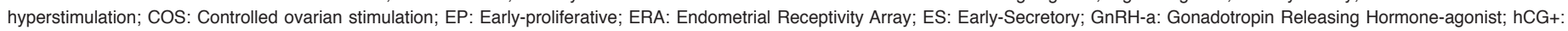

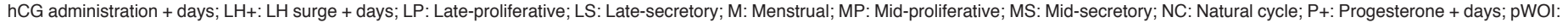
personalised window of implantation; rCG+: rCG administration + days; RIF: recurrent implantation failure. 
mediators, transcription factors, and cytokines with paracrine signalling (reviewed by Cha et al., 2013). Its objective identification using gene expression microarrays has been pursued since 2002.

Available data suggests that a 'transcriptional awakening process' takes place because most genes are upregulated compared to their expression in the pre-receptive phase (Riesewijk et al., 2003; Borthwick et al., 2003; Horcajadas et al., 2008; Haouzi et al., 2009 a, b; Díaz-Gimeno et. al. 2011). The early-secretory, or prereceptive, phase is characterised by the predominance of products related to cell metabolism (fatty acids, lipids, eicosanoids, and amino alcohols), transport (with a large representation of transporters for the biological molecules involved in these metabolic processes), germ cell migration (which could facilitate sperm transportation and ensure an aseptic environment), and negative cell-proliferation regulation. An increase in metabolism is consistent with the fact that this phase is biosynthetically highly active, which probably represents tissue preparation for embryo implantation; inhibition of mitosis during this phase is supported by the downregulation of numerous growth factors (Talbi et al., 2006).

Wnt pathway regulation during the secretory phase is very striking. Some, but not all ligands are downregulated, while some Wnt inhibitors, such as SFRP1 are repressed, but others such as DKK1 are highly upregulated compared to the proliferative phase (Talbi et al., 2006), and these further increase in the mid-secretory phase (Carson et al., 2002). The mid-secretory phase is characterised by its high level of metabolic and secretory activity, its non-proliferative phenotype, and increased sensitivity of the innate immune, stress, and wounding responses (Simmen and Simmen 2006; Giudice 2006; Talbi et al., 2006).

Genes whose expression changes during the transition between the early- and the mid-secretory phases, and the mid- and the late-secretory phases, are potential candidates for regulation by progesterone (Kao et al., 2002; Borthwick et al., 2003; Talbi et al., 2006). In fact, Ponnampalam et al., (2004) detected a cluster of genes that follow a temporal regulation pattern during the endometrial cycle which is very similar to the increase in circulating progesterone during these phases. These genes have been identified amongst those participating in some of the major biological processes which take place during implantation, such as signalling, growth, differentiation, and cell adhesion. However, there are no significant gene changes associated with the oestrogen peak (reviewed by Ruiz-alonso et al., 2012).

There are also genes that are overexpressed in the mid-secretory versus the early-secretory phases, and these are involved in processes related to cell adhesion, metabolism, response to external stimuli, signalling, immune responses, cell communication, and negative regulation of proliferation and development (Talbi et al., 2006; Díaz-Gimeno et al., 2011). The immune response plays an important role throughout the secretory phase. In the mid-secretory phase, the genes involved in the activation of the innate immune response are upregulated (including complements, antimicrobial peptides, and toll-like receptors), and there is also increased monocyte, T cell, and NK cell chemotaxis (CXCL14, granulysin, IL-15, carbohydrate sulfotransferase 2, and suppression of NK and T-cell activation, Talbi et al., 2006).

Some overexpressed genes protect the endometrium and/or the embryo in this phase (Talbi et al., 2006). GPX-3 is a seleniumdependent protein that has been associated with infertility in selenium-deficient women (Kingsley et al., 1998). It protects the cell from oxidative damage by catalysing the reduction of hydrogen peroxide, lipid peroxides, and organic hydroxyperoxide by glutathione (Riesewijk et al., 2003). DAF is a complement regulatoryprotein with two postulated functions: protection of the embryo from maternal complement-mediated attack, and prevention of epithelial destruction by increased expression of complement at the time of implantation (Franchi et al., 2008). This protein has been found in decreased levels in the endometrium of patients with recurrent abortion associated with antiphospholipid syndrome (Francis et al., 2006).

A study by Tseng et al., identified 126 upregulated genes in the mid- secretory phase compared to the late-secretory phase. Overexpressed processes included coagulation cascades and complex metabolism, including carbohydrates, glucose, lipids, cofactors, vitamins, xenobiotics, and amino acids, all of them suggesting that extracellular remodelling activity may occur in the mid-secretory phase (Tseng et al., 2010).

During the late secretory phase, oestrogen and progesterone levels decrease and the main processes regulated are extracellular matrix degradation, inflammatory response, and apoptosis (Giudice 2006; Simmen and Simmen 2006). In the transition from the mid- to the late-secretory phase, changes in the extracellular matrix and cytoskeleton favour processes such as vasoconstriction, smooth muscle contraction, haemostasis, and the transition from an immune to an inflammatory response (Critchley et al., 2001; Tseng et al., 2010). The genes that are regulated in this transition mostly relate to innate or humoral and cellular immune responses (Talbi et al., 2006), haemostasis, blood coagulation, steroid biosynthesis, and prostaglandin metabolism (Critchley et al., 2001). The processes represented in this late-secretory stage, such as matrix degradation, inflammatory response, and cell apoptosis, do not favour implantation. Thus, the transition from the mid- to the late-secretory phase defines the closure of the WOI and a return to the non-receptive endometrial phenotype, and an intense immune system activation (Talbi et al., 2006), which is consistent with the histological observation of leukocyte extravasation (Daly et al., 1982).

Regarding immune activation, the expression of Fc receptors, MHC molecules, and molecules secreted by $\mathrm{T}$ and NK cells are upregulated. This corresponds to the preparation of innate and adaptive immune responses: monocytes and granulocytes are primed to respond to antibodies because of Fc-receptor upregulation, and by expressing MHC-II molecules (Talbi et al., 2006). TNF alpha and IL beta are secreted by white blood cells present in the stromal cell compartment at the end of the cycle, and stimulate the release of matrix-degrading enzymes which contribute to degradation of the vascular basal membrane and connective tissue (Salamonsen and Woolley 1999). The above describes the predominant activities of the late-secretory phase and corresponds to decidualisation and preparation of the endometrium for the next menstrual phase, when the process starts again.

The effect of the embryo on endometrial transcriptomics has been investigated in vitro using a co-culture system involving human blastocysts and endometrial epithelial cells (De los Santos et al., 1998, Simón et al., 1997; Caballero Campo et al., 2002, Meseguer et al., 2001, Galan et al., 2013) which has also been translated to the clinic (Simón et al., 1999; Mercader et al., 2003). The transcriptomics of the endometrium during implantation has been analysed in vivo in a unique case report study in which an 
endometrial biopsy was taken in the mid-secretory phase from a patient who was later found to be pregnant at the time of sampling. The transcriptomics of this valuable sample were compared with samples from non-pregnant patients on the same day of the cycle, highlighting a total of 394 differentially expressed genes (Van Vaerenbergh et al., 2010). The major networks represented by these genes included post-translational modification, cell signalling, cell movement, cell development, and hematological function. These networks and canonical pathways form part of the molecular mechanisms known to be involved in an embryo-endometrial dialogue, and in implantation in both mice and humans. However, this study did not define the location of the endometrium analysed in relation to the embryo implantation site, and therefore some doubt remains as to whether the observed changes were due to embryo paracrine and/or maternal endocrine effects.

\section{Clinical translation of endometrial transcriptomics and personalised medicine}

A great challenge in biomedicine is understanding the relationship between the genotype and phenotype. The clinical objective is to visualise data that objectively links molecular profiles or gene signatures to function or disease phenotypes. The most widely used data exploration method is hierarchical clustering with visual heatmap representations (Fig. 1, 2A) and PCAs (Fig. 2B). With these types of analyses, the similarities of the various types of samples can be detected based on their transcriptomic profiles or signatures. In all the studies conducted (Riesewijk et al., 2003; Ponnampalam et al., 2004; Talbi et al., 2006; Tseng et al., 2010; Critchley et al., 2006; Diaz-Gimeno et al., 2011, 2013), samples clearly group according to the stage to which they belong. In general, the phase assignment is made based on previous histological dating in these studies, and is usually performed by at least two independent pathologists (Díaz-Gimeno et al., 2013).

Sample grouping, according to the endometrial cycle phase is clearly observable using hierarchical clustering methods, especially where the entire menstrual cycle is analysed. Two important studies grouped samples into two main branches, which were further divided into other sub-branches (Ponnampalam et al., 2004; Talbi et al., 2006). One major branch contains the proliferative and early-secretory phases, as well as the menstrual phase (Ponnampalam et al., 2004), while the other main branch groups include samples from the mid-secretory and the late-secretory phases (Talbi et al., 2006). Subsequent PCA analysis on both data sets detected four clusters of samples, corresponding to the predominant proliferative, early-secretory, mid-secretory, or late-secretory phases. Despite the sets of genes used for PCA and hierarchical clustering in these studies being different, the same clusters were found by both methods. In addition, although six samples were dated histologically as 'ambiguous', both PCA

B and hierarchical clustering categorised them in the same phase. These facts provide evidence for the existence of well-defined transcriptomic profiles for each phase. Our group also defined the transcriptomic transition between the pre-receptive to receptive status in natural and controlled ovarian stimulated cycles (COS) (Horcajadas et al., 2008). These studies all conclude that it is possible to accurately catalogue the endometrium at different stages based on its transcriptomic profiles, thus facilitating the transition from anatomical to molecular medicine for the human endometrium.

Personalised, or stratified, medicine has been used in reproductive medicine in diverse clinical situations, including adjusting $\mathrm{FSH} / \mathrm{LH}$ dosages using the body mass index and according to the ovarian reserve as assessed by the presence or absence of specific biomarkers, the selection of specific fertilisation techniques (e.g., intracytoplasmic sperm injection, in vitro fertilization (IVF) or both according to sperm features and the clinical background), and monitoring embryo development in vitro.

Since the last century, endometrial receptivity has been studied from the morphological, biochemical, molecular, and cellular points of view, however, none of the proposed markers have become diagnostic tools because they offer a low predictive value
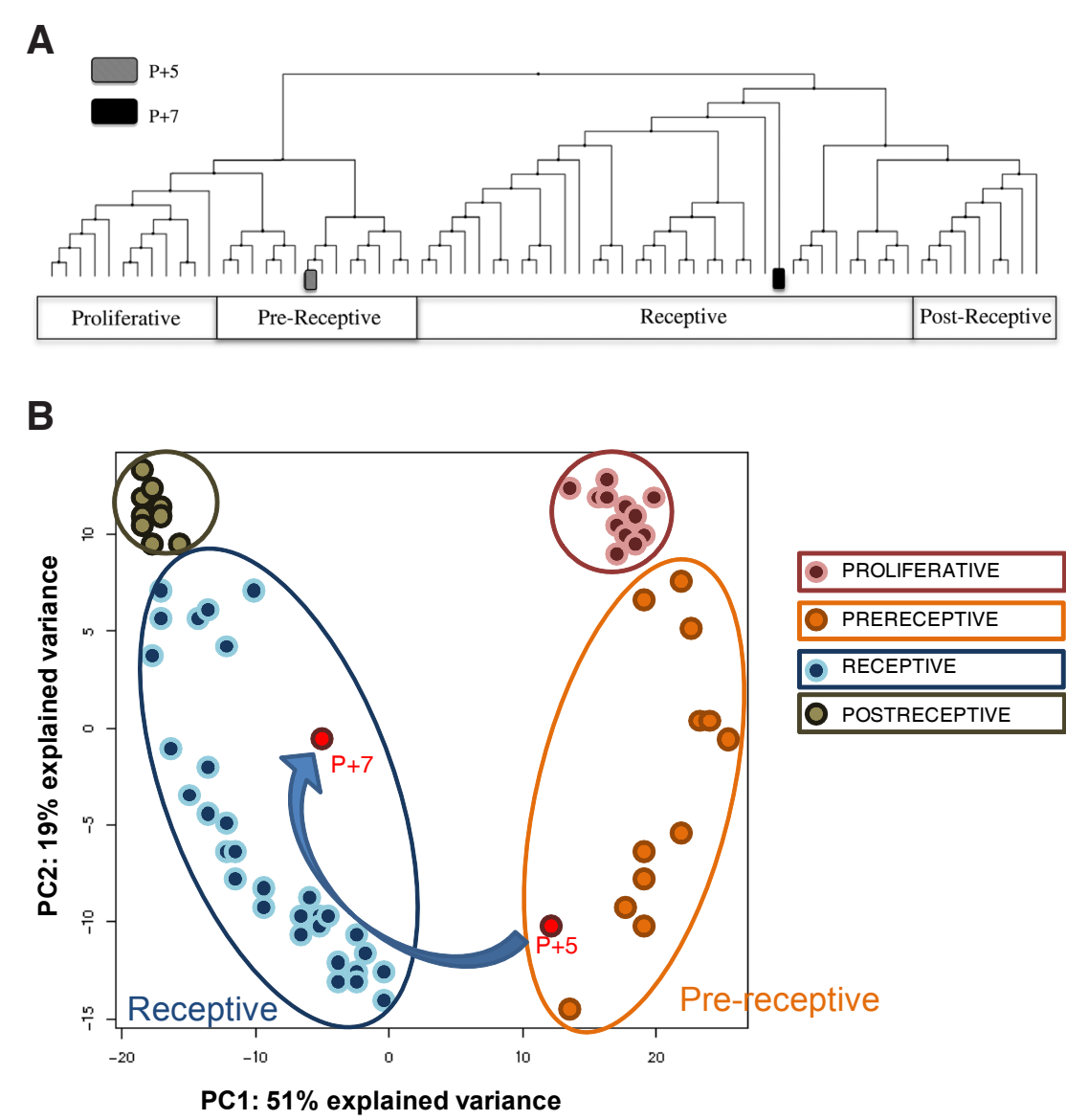

Fig. 2. Personalised Window Of Implantation (pWOI). Clustering (A) and Principal Component Analysis (PCA) (B) of genes identified in two samples from the same patient, taken at different times, cluster with the Endometrial Receptivity Array (ERA) test training set genes. The first sample was taken after five days with progesterone $(P+5)$ and shows a pre-receptive profile, but a sample taken two days later, at $P+7$, shows a receptive endometrial profile. 
(Haouzi et al., 2012; Aghajanova et al., 2008 a,b; Martin et al., 2002; Lessey 2011). Many studies searching for endometrial markers have focused on single molecules or on specific families of molecules (Hynes 1992; Lessey et al., 1992; Meseguer et al., 2001; Dubowy et al., 2003) reaching the conclusion that a single molecule is not sufficient to describe such a complex phenomenon. By acknowledging this fact, transcriptomic profiles may prove to be complex enough to classify the different endometrial cycle phases, including the window of endometrial receptivity (Fig. 1).

\section{The Endometrial Receptivity Array (ERA)}

Given the need for reliable, objective, molecular dating methods for the endometrium, our group developed a specific tool to identify the transcriptomic signature of the window of endometrial receptivity, called ERA (DíazGimeno et al., 2011, 2013).

The ERAis a customised array that has been designed to identify the endometrial receptivity status by comparing the transcriptomic profile of a test sample with those of control samples from 7 days after the luteinising hormone peak $(\mathrm{LH}+7)$ in a natural cycle, or five days after $\mathrm{P}$ administration $(\mathrm{P}+5)$ after E2 priming in a hormonal replacement therapy (HRT) cycle. It contains 238 genes that are differentially expressed between these profiles, which are coupled to a computational predictor that can diagnose the personalised endometrial WOI of a given patient regardless of their endometrial histology (Díaz-Gimeno et al., 2013). The predictor was trained with gene expression profiles obtained from samples at different stages of the menstrual cycle (proliferative, pre-receptive, receptive, and post-receptive) in order to be able to classify a test sample according to the gene expression values obtained with the array. This classification has a specificity and sensitivity of 0.8857 and 0.99758 respectively (Díaz-Gimeno et al., 2011). The ERA is more accurate than histological dating and is a highly reproducible method, even up to 40 months after first diagnosing the personalised WOI (Díaz-Gimeno et al., 2013). Hence, for the first time, a molecular tool based on the expression of a cluster of endometrial biomarker genes has been clinically used in reproductive medicine to assess the endometrial factor with proven accuracy and consistency. This molecular signature can now be used to personalise the definition of patients' WOI and to investigate the effect of different treatments or conditions on the receptivity status of the human endometrium, or in the search for new, less invasive methods to evaluate receptiveness.

The diagnostic and clinical value of the ERA test in patients with recurrent implantation failure (RIF) has been tested in a prospective interventional, multicentre, clinical trial (Ruiz-Alonso et al., 2013). Patients with at least three previous failed ovum donation cycles, and IVF patients less than 40 years old with at least three failed IVF cycles, composed the RIF group. Patients with no failed ART cycles composed the control group.

In this trial, RIF and control patients underwent ERA-based endometrial receptivity diagnosis using an endometrial biopsy obtained either on day $\mathrm{LH}+7$ in a natural cycle or on day $\mathrm{P}+5$ in an HRT cycle (Ruiz-Alonso et al., 2013). One of the most signifi-

cant results was that the ERA test identified $88 \%$ of the samples as receptive versus $12 \%$ as non-receptive in the control group, while in the RIF group $74.1 \%$ of the samples were receptive versus $25.9 \%$ which were non-receptive. In other words one in four patients with RIF has a displaced WOI and therefore their incapability to implant can be attributed to the endometrial factor.

The 'non-receptive' diagnosis, not only indicates that the endometrium is not ready for embryo adhesion, therefore making embryo transfer futile at this moment, but also gives us information about their profile of pre-receptivity or post-receptivity status (Fig. $2 \mathrm{~A}, \mathrm{~B})$. Although it has been assumed that the WOI is constant in time in all women, now with the information obtained from this transcriptomical tool, we learned that the capability to diagnose a displacement of the WOI and to personalised embryo transfer $(p E T)$ in each patient. Then, pET was applied in patients who had an initial non-receptive result at the first biopsy, who then achieved a $50.0 \%$ pregnancy rate and a $38.5 \%$ implantation rate. This is very close to that of patients who had a receptive result at their first biopsy: $51.7 \%$ and $33.9 \%$ respectively (Ruiz-Alonso et al., 2013).

Until now, the stage of embryo development has been the primary factor guiding the timing of embryo transfer in ART because it was generally accepted that the timing and duration of the WOI was constant in all women. However, our work has shown that with the information obtained from the ERA transcriptomic tool it is possible to identify the status of the endometrium using the transcriptomic profile of a selected group of genes to identify a delayed or advanced WOI (Fig. 3). Therefore, we now have the ability to diagnose displacement of the WOI and to personalise embryo transfer in each patient as necessary (Ruiz-Alonso et al., 2013), and so helping to improve clinical success from the endometrial perspective using this novel approach (Fig. 3). This highlights the need to synchronize embryonic and endometrial development, personalising the timing of embryo transfer.

Although this molecular tool has already been demonstrated as effective in RIF patients, a prospective, randomised clinical trial on the effectiveness of the ERA test in the infertility work-up 
is also ongoing and is registered at U.S. National Institutes of Health (NCT:01954758 http://clinicaltrials.gov/).

\section{Future directions in the transcriptomics of human endometrium}

In addition to gene expression microarrays, technology to measure gene expression called RNA sequencing (RNA-seq), based on next generation sequencing (NGS), is also emerging. This new technology is capable of true genome-wide analysis, sequencing all the mRNAs present in a sample. $25 \%$ of genes with low expression remain undetected with standard microarray technologies but are detected in RNA-seq reads (Wang et al., 2009; Mane et al., 2009). Studies that compare results derived from an Affymetrix microarray study and an RNA-seq study of bovine endometrium revealed a consistent overlap between the results but there were many more differentially expressed genes in the sequencing data set (Mane et al., 2009; Ulbrich et al., 2013).

The development and popularisation of the high-throughput tecnologies in the post-genomic era (microarrays, GWAS, NGS, etc.) have increased both the volume and the accuracy of data processing and have revolutionised medical diagnoses and treatments. However, this situation does not yet correspond to the expectation of an improved ability to diagnose disease-associated genes, therefore, whether these technological improvements will translate into clinical diagnostic advances, remains to be seen.

Functional analysis methods operate best on large (preferably whole genome) data sets, which are nonstringently filtered by fold change, $p$-values or false discovery rate thresholds, (Chen et al., 2007), or in data sets not limited in size at all (GSEA; Subramanian et al., 2005): i.e. the opposite of the trend for reducing the size of data sets used in transcriptomics analysis.

Transcriptomics in the human endometrium remains a research focus, not only from the perspective of NGS analysis, but much more for its potential in the analysis of gene expression data from functional genomics analysis from different biological perspectives. Moreover, the systemic approach of systems biology analysis, via networks and other statistical and mathematical analysis methods remains to be developed. New functional analysis, based on the systems biology approach has been applied to endometrial physiology by some groups already (van Vaerenbergh et al., 2010; Altmäe et al., 2012). For example, Bourgain's group, performed network analysis on differentially expressed genes to reveal 30 networks involved in implantation (van Vaerenbergh et al., 2010) and Altmäe et al., described the complex molecular network of the implantation process in humans in which embryonic and endometrial transcriptomic profiles were integrated with protein-protein interactions (Altmäe et al., 2012). Nevertheless, this new systems approach must still be further developed in order to integrate and mathematically model the data so that information about functional genomics in normal and disease endometrial physiology can be deduced (Wang et al., 2010).

The new highthroughput technologies and their associated computational analysis have to evolve and develop much more before they can be considered cutting-edge technologies. Transcriptomics, based on microarray technology, currently has sufficiently standarised procedures to allow them to be applied clinically, although their functional relevance still remains unclear. However, the current standard in RNA-seq, the definition of the transcriptome using NGS platforms is likely to be challenged by newer global gene-expression analysis technologies, as reported by the MAQC consortium (Mane et al., 2009). While RNA-seq technology is improving the precision of our knowledge of the transcriptome by detecting previously undiscovered alternative splicing variants, this improved-sensitivity NGS method and systems biology approach combined together could be used to elucidate even more about embryo implantation using transcriptomics.

\section{References}

AGHAJANOVA L, HAMILTON AE, GIUDICE LC (2008a). Uterine receptivity to human embryonic implantation: histology, biomarkers, and transcriptomics. Semin Cell Dev Biol 19: 204-211.

AGHAJANOVA L, SIMON C, HORCAJADAS JA (2008b). Are favorite molecules of endometrial receptivity still in favor?. Expert Rev Obstet Gynecol 3: 487-501.

ALTMÄE S, ESTEBAN FJ, STAVREUS-EVERS A, SIMÓN C, GIUDICE L, LESSEY BA, HORCAJADAS JA, MACKLON NS, D'HOOGHE T, CAMPOY C, FAUSER BC, SALAMONSEN LA, SALUMETSA (2013). Guidelines for the design, analysis and interpretation of 'omics' data: focus on human endometrium. Hum Reprod Update 20: 12-18.

ALTMÄE S, MARTINEZ-CONEJERO JA, SALUMETS A, SIMON C, HORCAJADAS JA, STAVREUS-EVERS A (2010). Endometrial gene expression analysis at the time of embryo implantation in women with unexplained infertility. Mol Hum Reprod 16: 178-187.

ALTMÄE S, REIMAND J, HOVATTA O, ZHANG P, KERE J, LAISK T, SAARE M, PETERS M, VILO J, STAVREUS-EVERS A, SALUMETS A (2012). Research resource: interactome of human embryo implantation: identification of gene expression pathways, regulation, and integrated regulatory networks. Mol Endocrinol 26: 203-217.

ASHBURNER M, BALL CA, BLAKE JA, BOTSTEIN D, BUTLER H, CHERRY JM DAVIS AP, DOLINSKI K, DWIGHT SS, EPPIG JT, HARRIS MA, HILL DP, ISSELTARVERL, KASARSKISA, LEWISS, MATESE JC, RICHARDSON JE, RINGWALD M, RUBIN GM, SHERLOCK G (2000). Gene Ontology: tool for the unification of biology. The Gene Ontology Consortium. Nat Genet 25: 25-29.

BEISVÅG V, KAUFFMANNA, MALONEJ, FOYC, SALITM, SCHIMMELH, BONGCAMRUDLOFF E, LANDEGRENU, PARKINSON H, HUBERW, BRAZMAA, SANDVIK AK, KUIPER M (2011). Contributions of the EMERALD project to assessing and improving microarray data quality. Biotechniques 50: 27-31.

BERLANGA O, BRADSHAW HB, VILELLA-MITJANA F, GARRIDO-GÓMEZ T, SIMÓN C (2011). How endometrial secretomics can help in predicting implantation. Placenta 3: S271-S275.

BERMEJO A, CERRILLO M, RUIZ-ALONSO M, BLESA D, SIMÓN C, PELLICER A, GARCIA-VELASCO JA (2013). Impact of final oocyte maturation using gonadotropin-releasing hormone agonist triggering and different luteal support protocols on endometrial gene expression. Fertil Steril S0015-0282(13)03107-5.

BLOCKEEL C, VAN VAERENBERGH I, FATEMI HM, VAN LOMMEL L, DEVROEY $P, B O U R G A I N C$ (2011). Gene expression profile in the endometrium on the day of oocyte retrieval after ovarian stimulation with low-dose hCG in the follicular phase. Mol Hum Reprod 1: 33-41.

BORTHWICK J, CHARNOCK-JONES S, TOM BD, HULL ML, TEIRNEY R, PHILLIPS SC, SMITH SK (2003). Determination of the transcript profile of human endometrium. Mol Hum Reprod 9: 19-33.

BRAZMA A, HINGAMP P, QUACKENBUSH J, SHERLOCK G, SPELLMAN P, STOECKERT C, AACH J, ANSORGE W, BALL CA, CAUSTON HC, GAASTERLAND T, GLENISSON P, HOLSTEGE FC, KIM IF, MARKOWITZ V, MATESE JC, PARKINSON H, ROBINSON A, SARKANS U, SCHULZE-KREMER S, STEWART J, TAYLOR R, VILO J, VINGRON M (2001). Minimum information about a microarray experiment (MIAME)-toward standards for microarray data. Nat Genet 29: 365-371.

CABALLERO-CAMPO P, DOMÍNGUEZ F, COLOMA J, MESEGUER M, REMOHÍ J, PELLICER A, SIMÓN C (2002). Hormonal and embryonic regulation of chemokines IL-8, MCP-1 and RANTES in the human endometrium during the window of implantation. Mol Hum Reprod 8: 375-384.

CARSON D, LAGOW E, THATHIAH A, AL-SHAMI R, FARACH-CARSON MC, VERNON M, YUAN L, FRITZ MA, LESSEY B (2002). Changes in gene expression 
during the early to mid-luteal (receptive phase) transition in human endometrium detected by high-density microar- ray screening. Mol Hum Reprod 8: 971-979.

CHA J, VILELLA F, DEY SK AND SIMÓN C. "Molecular Interplay in Successful Implantation" in Ten Critical Topics in Reproductive Medicine, S. Sanders, Ed. (Science/AAAS, Washington, DC, 2013), pp. [44-48].

CHEN JJ, WANG SJ, TSAI CA, LIN CJ (2007). Selection of differentially expressed genes in microarray data analysis. Pharmacogenomics $J$ 7: 212-220.

COUTIFARIS C, MYERS ER, GUZICK DS, DIAMOND MP, CARSON SA, LEGRO RS, MCGOVERN PG, SCHLAFF WD, CARR BR, STEINKAMPF MP, SILVA S, VOGELDL, LEPPERTPC; NICHD NATIONALCOOPERATIVE REPRODUCTIVE MEDICINE NETWORK (2004). Histological dating of timed endometrial biopsy tissue is not related to fertility status. Fertil Steril 82: 1264-1272.

CRITCHLEY HO, K.A. ROBERTSON, T. FORSTER, T.A. HENDERSON, A.R. WILLIAMS, P. GHAZAL (2006). Gene expression profiling of mid to late secretory phase endometrial biopsies from women with menstrual complaint. Am J Obstet Gynecol 195: 406.e1-406.16.

CRITCHLEY HO, KELLY RW, BRENNER RM, BAIRD DT (2001). The endocrinology of menstruation-a role for the immune system. Clin Endocrinol(Oxf) 55: 701-710.

CROXATTO HB, ORTIZ ME, DÍAZ S, HESS R, BALMACEDA J, CROXATTO HD (1978). Studies on the duration of egg transport by the human oviduct. II. Ovum location at various intervals following luteinizing hormone peak. Am J Obstet Gynecol 132: 629-634.

DALY DC, TOHAN N, DONEYTJ, MASLAR IA, RIDDICKDH (1982). The significance of lymphocytic-leukocytic infiltrates in interpreting late luteal phase endometrial biopsies. Fertil Steril 37: 786-791.

DE LOS SANTOS MJ, ANDERSON DJ, RACOWSKY C, SIMÓN C, HILL JA (1998). Expression of interleukin-1 system genes in human gametes. Biol Reprod 59: 1419-1424.

DÍAZ-GIMENO P, HORCAJADAS JA, MARTÍNEZ-CONEJERO JA, ESTEBAN FJ, ALAMA P, PELLICER A, SIMÓN C (2011). A genomic diagnostic tool for human endometrial receptivity based on the transcriptomic signature. Fertil Steril95:50-60.

DÍAZ-GIMENO P, RUIZ-ALONSO M, BLESAD, BOSCH N, MARTÍNEZ-CONEJERO JA, ALAMÁ P, GARRIDO N, PELLICER A, SIMÓN C (2013). The accuracy and reproducibility of the endometrial receptivity array is superior to histology as a diagnostic method for endometrial receptivity. Fertil Steril 99: 508-517.

DOLL A, ABAL M, RIGAU M, MONGE M, GONZALEZ M, DEMAJO S, COLÁS E, LLAURADÓ M, ALAZZOUZI H, PLANAGUMÁ J, LOHMANN MA, GARCIA J, CASTELLVIS, RAMON Y CAJAL J, GIL-MORENO A, XERCAVINS J, ALAMEDA F, REVENTÓS J (2008). Novel molecular profiles of endometrial cancer-new light through old windows. J Steroid Biochem Mol Biol 108: 221-229.

DUBOWY RL, FEINBERG RF, KEEFE DL, DONCEL GF, WILLIAMS SC, MCSWEET JC, KLIMAN HJ (2003). Improved endometrial assessment using cyclin E and p27. Fertil Steril 80: 146-56.

EVANS GE, MARTINEZ-CONEJERO JA, PHILLIPSON GT, SIMON C, MCNOE LA, SYKES PH, HORCAJADAS JA, LAM EY, PRINT CG, SIN IL, EVANS JJ (2012). Gene and protein expression signature of endometrial glandular and stromal compartments during the window of implantation. Fertil Steril 97: 1365-1373.e2.

FASSBENDER A, VODOLAZKAIA A, SAUNDERS P, LEBOVIC D, WAELKENS E, DE MOOR B, D'HOOGHE T (2013). Biomarkers of endometriosis. Fertil Steril 99: 1135-1145.

FINN CL, MARTIN L (1974). Control of implantation. J Reprod Fertil 39: 195-206.

FRANCHI A, ZARET J, ZHANG X, BOCCA S, OEHNINGER S (2008). Expression of immunomodulatory genes, their protein products and specific ligands/receptors during the window of implantation in the human endometrium. Mol Hum Reprod 14: 413-421.

FRANCIS J, RAI R, SEBIRE NJ, EL-GADDAL S, FERNANDES MS, JINDAL P, LOKUGAMAGE A, REGAN L, BROSENS JJ (2006). Impaired expression of endometrial differentiation markers and complement regulatory proteins in patients with recurrent pregnancy loss associated with antiphospholipid síndrome. $\mathrm{Mol}$ Hum Reprod 12: 435-442.

GALAN A, DÍAZ-GIMENO P, POO ME, VALBUENA D, SANCHEZ E, RUIZ V, DOPAZO J, MONTANER D, CONESA A, SIMON C (2013). Defining the genomic signature of totipotency and pluripotency during early human development. PLOS One 8: e62135.

GARRIDO-GÓMEZ T, RUIZ-ALONSO M, BLESA D, DIAZ-GIMENO P, VILELLA F, SIMÓN C (2013). Profiling the gene signature of endometrial receptivity: clinical results. Fertil Steril 99: 1078-1085.

GIUDICE LC (1999). Potential biochemical markers of uterine receptivity. Hum Reprod 14: 3-16

GIUDICE LC (2006). Application of functional genomics to primate endometrium: insights into biological processes. Reprod Biol Endocrinol 4(Suppl. 1):S4.

HAOUZI D, ASSOU S, DECHANET C, ANAHORY T, DECHAUD H, DE VOS J, HAMAMAH S (2010). Controlled ovarian hyperstimulation for in vitro fertilization alters endometrial receptivity in humans: protocol effects. Biol Reprod82: 679-686.

HAOUZI D, ASSOU S, MAHMOUD K, TONDEUR S, REME T, B. HEDON, DE VOS J, HAMAMAHS (2009b). Gene expression profile of human endometrial receptivity: comparison between natural and stimulated cycles for the same patients. Hum Reprod 24: 1436-1445.

HAOUZI D, DECHAUD H, ASSOU S, DE VOS J, HAMAMAH S (2012). Insights into human endometrial receptivity from transcriptomic and proteomic data. Reprod Biomed Online 24: 23-34.

HAOUZI D, MAHMOUD K, FOURAR M, BENDHAOU K, DECHAUD H (2009a). Identification of new biomarkers of human endometrial receptivity in the natural cycle. Hum Reprod 24: 198-205.

HARPER MJ (1992). The implantation window. Baillieres Clin Obstet Gynaecol 6: 351-371.

HORCAJADAS JA, PELLICER A, SIMON C (2007). Wide genomic analysis of human endometrial receptivity: new times, new opportunities. Hum Reprod Update 13: 77-86.

HORCAJADAS JA, RIESEWIJK A, DOMINGUEZ F, CERVERO A, PELLICER A, SIMON C (2004). Determinants of endometrial receptivity. Ann N Y Acad Sci 1034: 166-175.

HORCAJADAS JA, RIESEWIJK A, MÍNGUEZ P, DOPAZO J, ESTEBAN FJ, DOMÍNGUEZ F, GIUDICE LC, PELLICERA, SIMÓN C (2008). Gene expression analysis of the endometrium reveals that controlled ovarian stimulation induces a genomic delay with potential clinical implications. J Clin Endocrinol Metab 93: 4500-4510.

HORCAJADAS JA, RIESEWIJK A, POLMAN J, VAN OS R, PELLICER A, MOSSELMAN S, SIMÓN C (2005). Effect of controlled ovarian hyperstimulation in IVF on endometrial gene expression profiles. Mol Hum Reprod 11: 195-205.

HYNES R.O. (1992), Integrins: versatility, modulation, and signaling in cell adhesión. Cell 69: 11-25.

KANEHISA M, GOTO S (2000). KEGG: Kyoto encyclopedia of genes and genomes. Nucleic Acids Res 28: 27-30.

KAO LC, TULAC S, LOBO S, IMANI B, YANG JP, GERMEYER A, OSTEEN K, TAYLOR RN, LESSEY BA, GIUDICE LC (2002). Global gene profiling in human endometrium during the window of implantation. Endocrinology 143: 2119-2138.

KINGSLEY PD, WHITIN JC, COHEN HJ, PALIS J (1998). Developmental expression of extracellular glutathione peroxidase suggests antioxidant roles in deciduum, visceral yolk sac, and skin. Mol Reprod Dev 49: 343-355.

KOLER M, ACHACHE H, TSAFRIR A, SMITH Y, REVEL A, REICH R (2009). Disrupted gene pattern in patients with repeated in vitro fertilization (IVF) failure. Hum Reprod 24: 2541-2548.

LABARTA E, MARTÍNEZ-CONEJERO JA, ALAMA P, HORCAJADAS JA, PELLICER A, SIMON C, BOSCHE (2011). Endometrial receptivity is affected in women with high circu- lating progesterone levels at the end of the follicular phase: a functional genomics analysis. Hum Reprod 26: 1813-1825.

LESSEY BA (2000). Endometrial receptivity and the window of implantation. Baillieres Best Pract Res Clin Obstet Gynaecol 14: 775-788.

LESSEY BA (2011). Assessment of endometrial receptivity. Fertil Steril 96: 522-529. LESSEYBA, L. DAMJANOVICH, C. COUTIFARIS, A. CASTELBAUM, S.M. ALBELDA, C.A (1992). Buck, Integrin adhesion molecules in the human endometrium. Correlation with the normal and abnormal menstrual cycle. J Clin Invest 90: 188-195.

LIU Y, LEE KF, NG EH, YEUNG WS, HO PC (2008). Gene expression profiling of human peri-implantation endometria between natural and stimulated cycles. Fertil Steril 90: 2152-64.

MACKLON NS, VAN DER GAAST MH, HAMILTON A, FAUSER BC, GIUDICE LC (2008). The impact of ovarian stimulation with recombinant $\mathrm{FSH}$ in combination with $\mathrm{GnRH}$ antagonist on the endometrial transcriptome in the window of implantation. Reprod Sci 15: 357-365.

MANE SP, EVANS C, COOPER KL, CRASTA OR, FOLKERTS O, HUTCHISON SK, HARKINS TT, THIERRY-MIEG D, THIERRY-MIEG J, JENSEN RV (2009). 
Transcriptome sequencing of the Microarray Quality Control (MAQC) RNA reference samples using next generation sequencing. BMC Genomics 12 10: 264. doi: 10.1186/1471-2164-10-264.

MAQC CONSORTIUM (2006). The MicroArray Quality Control (MAQC) project shows inter- and intraplatform reproducibility of gene expression measurements. Nat Biotechnol 24: 1151-1161.

MAQC CONSORTIUM (2010). The MicroArray Quality Control (MAQC)-II study of common practices for the development and validation of microarray- based predictive models. Nat Biotechnol 28: 827-838.

MARTÍN J, DOMÍNGUEZ F, AVILA S, CASTRILLO JL, REMOHÍ J, PELLICER A, et al., (2002). Human endometrial receptivity: gene regulation. J Reprod Immunol 55: $131-139$.

MARTÍNEZ-CONEJERO JA, SIMON C, PELLICER A, HORCAJADAS JA (2007). Is ovarian stimulation detrimental to the endometrium?. Reprod Biomed Online 15: 45-50.

MATSUZAKI S (2011). DNA microarray analysis in endometriosis for development of more effective targeted therapies. Front Biosci (Elite Ed) 3: 1139-1153.

MEDINA I, CARBONELL J, PULIDO L, MADEIRA SC, GOETZ S, CONESA A, TÁRRAGAJ, PASCUAL-MONTANOA, NOGALES-CADENASR, SANTOYOJ, GARCÍA F, MARBÀ M, MONTANER D, DOPAZO J (2010). Babelomics: an integrative platform for the analysis of transcriptomics, proteomics and genomic data with advanced functional profiling. Nucleic Acids Res 38: W210-W213.

MEDINA I, MONTANER D, TARRAGA J, DOPAZO J (2007). Prophet, a web-based tool for class prediction using microarray data. Bioinformatics 23: 390-391.

MERCADER A, GARCIA-VELASCO JA, ESCUDERO E, REMOHÍ J, PELLICER A, SIMÓN C (2003). Clinical experience and perinatal outcome of blastocyst transfer after coculture of human embryos with human endometrial epithelial cells: a 5-year follow-up study. Fertil Steril 80: 1162-1168.

MESEGUER M, APLIN JD, CABALLERO-CAMPO P, O'CONNOR JE, MARTíN JC, REMOHÍ J, PELLICER A, SIMÓN C (2001). Human endometrial mucin MUC1 is up-regulated by progesterone and down-regulated in vitro by the human blastocyst. Biol Reprod 64: 590-601

MIRKIN S, ARSLAN M, CHURIKOV D, CORICA A, DIAZ JI, WILLIAMS S, BOCCA S, OEHNINGER $S$ (2005). In search of candidate genes critically expressed in the human endometrium during the window of implantation. Hum Reprod 20: 2104-2117.

MIRKIN S, NIKAS G, HSIU JG, DIAZ J, OEHNINGER S (2004). Gene expression profiles and structural/functional features of the peri-implantation endometrium in natural and gonadotropin-stimulated cycles. J Clin Endocrinol Metab89:5742-5752.

MIRNEZAMI R, NICHOLSON J, AND DARZI A (2012). Preparing for Precision Medicine. N Engl J Med 366: 489-91.

MURRAY MJ, MEYER WR, ZAINO RJ, LESSEY BA, NOVOTNY DB, IRELAND K, ZENG D, FRITZ MA (2004). A critical analysis of the accuracy, reproducibility, and clinical utility of histologic endometrial dating in fertile women. Fertil Steril 81: 1333-1343.

NEVINS JR, POTTIA (2007). Mining gene expression profiles: expression signatures as cancer phenotypes. Nat Rev Genet 8: 601-609.

NOYES RW, HERTIG AT, ROCK J (1950). Dating the endometrial biopsy. Fertil Steril 1: 3-25.

NOYES RW, HERTIG AT, ROCK J (1975). Dating the endometrial biopsy. Am J Obstet Gynecol 122: 262-263.

PETRACCO RG, KONG A, GRECHUKHINA O, KRIKUN G, TAYLOR HS (2012). Global gene expression profiling of proliferative phase endometrium reveals distinct func- tional subdivisions. Reprod Sci 10: 1138-1145.

PONNAMPALAMAP, WESTONGC, TRAJSTMANAC, SUSILB, ROGERSPA(2004). Molecular classification of human endometrial cycle stages by transcriptional profiling. Mol Hum Reprod 10: 879-893.

PUNYADEERA C, DASSEN H, KLOMP J, DUNSELMAN G, KAMPS R, DIJCKS F, EDERVEENA, DE GOEIJ A, GROOTHUIS P (2005). Oestrogen-modulated gene expression in the human endometrium. Cell Mol Life Sci 62: 239-250.

QUACKENBUSH J (2006). Microarray analysis and tumor classification. N Engl J Med 354: 2463-2472.

RIESEWIJKA, MARTINJ, HORCAJADASJA, POLMANJ, PELLICERA, MOSSELMAN S, SIMÓN C (2003). Gene expression profiling of human endometrial receptivity on days LH2 versus LH7 by microarray technology. Mol Hum Reprod 9: 253-64.
RUIZ-ALONSO M, BLESAD, DíAZ-GIMENO P, GÓMEZE, FERNÁNDEZ-SÁNCHEZ M, CARRANZA F, CARRERA J, VILELLA F, PELLICER A, SIMÓN C (2013). The endometrial receptivity array for diagnosis and personalized embryo transfer as a treatment for patients with repeated implantation failure. Fertil Steril 100: 818-824.

RUIZ-ALONSO M, BLESA D, SIMÓN C (2012). The genomics of the human endometrium. Biochim Biophys Acta 1822: 1931-1942.

SALAMONSEN LA, HANNAN NJ, DIMITRIADISE (2007). Cytokines and chemokines during human embryo implantation: roles in implantation and early placentation. Semin Reprod Med 25: 437-444.

SALAMONSEN LA, WOOLLEY DE (1999). Menstruation: induction by matrix metalloproteinases and inflammatory cells. J Reprod Immunol 44: 1-27.

SCHENA M, SHALON D, DAVIS RW, BROWN PO (1995). Quantitative monitoring of gene expression patterns with a complementary DNA microarray. Science 270: 467-470.

SHI W, BESSARABOVAM, DOSYMBEKOV D, DEZSOZ, NIKOLSKAYAT, DUDOLADOVAM SEREBRYISKAYAT, BUGRIM A, GURYANOVA, BRENNAN RJ, SHAH R, DOPAZO J, CHEN M, DENG Y, SHIT, JURMAN G, FURLANELLO C, THOMAS RS, CORTON JC, TONG W, SHI L, NIKOLSKY Y (2010). Functional analysis of multiple genomic signatures demonstrates that classification algorithms choose phenotype-related genes. Pharmacogenomics J 10: 310-323.

SIMMEN FA, SIMMEN RC (2006). Orchestrating the menstrual cycle: discerning the music from the noise. Endocrinology 147: 1094-1096.

SIMÓN C, GIMENO MJ, MERCADER A, O'CONNOR JE, REMOHÍ J, POLAN ML, PELLICERA (1997). Embryonic regulation of integrins beta 3, alpha 4, and alpha 1 in human endometrial epithelial cells in vitro. JClin EndocrinolMetab82:2607-2616.

SIMÓN C, MERCADER A, GARCIA-VELASCO J, NIKAS G, MORENO C, REMOHÍ J, PELLICER A (1999). Coculture of human embryos with autologous human endometrial epithelial cells in patients with implantation failure. J Clin Endocrinol Metab 84: 2638-2646.

SIMÓN C, OBERYE J, BELLVER J, VIDAL C, BOSCH E, HORCAJADAS JA, MURPHY C, ADAMS S, RIESEWIJK A, MANNAERTS B, PELLICER A (2005). Similar endometrial development in oocyte donors treated with either high- or standard-dose $\mathrm{GnRH}$ antagonist compared to treatment with a $\mathrm{GnRH}$ agonist or in natural cycles. Hum Reprod 20: 3318-3327.

SIMON R (2003). Using DNA microarrays for diagnostic and prognostic prediction. Expert Rev Mol Diagn 3: 587-595.

SPITZERTL, ROJAS A, ZELENKOZ, AGHAJANOVAL, ERIKSON DW, BARRAGAN F, MEYER M, TAMARESIS JS, HAMILTON AE, IRWIN JC, GIUDICE LC (2012). Perivascular human endometrial mesenchymal stem cells express pathways relevant to self-renewal, lineage specification, and functional phenotype. Biol Reprod 86: 58.

STUART JM, SEGAL E, KOLLER D, KIM SK (2003). A gene-coexpression network for global discovery of conserved genetic modules. Science 302: 249-255.

SUBRAMANIANA, TAMAYOP, MOOTHAVK, MUKHERJEES, EBERTBL, GILLETTE MA, PAULOVICH A, POMEROY SL, GOLUB TR, LANDER ES, MESIROV JP (2005). Gene set enrichment analysis: a knowledge-based approach for interpreting genome-wide expression profiles. Proc Natl Acad Sci USA 102: 15545-15550.

TALBI S, HAMILTON AE, VO KC, TULAC S, OVERGAARD MT, DOSIOU C, LE SHAY N, NEZHAT CN, KEMPSON R, LESSEY BA, NAYAK NR, GIUDICE LC (2006). Molecular phenotyping of human endometrium distinguishes menstrual cycle phases and underlying biological processes in normo-ovulatory women. Endocrinology 147: 1097-121.

TSENG LH, CHEN I, CHEN MY, YAN H, WANG CN, LEE CL (2010). Genome-based ex-pression profiling as a single standardized microarray platform for the diagnosis of endometrial disorder: an array of 126-gene model. Fertil Steril 94: 114-119.

ULBRICH SE, GROEBNER AE, BAUERSACHS S (2013). Transcriptional profiling to address molecular determinants of endometrial receptivity - lessons from studies in livestock species. Methods 59: 108-115.

VAN 'T VEER LJ, DAI H, VAN DE VIJVER MJ, HE YD, HART AA, MAO M, PETERSE HL, VAN DER KOOY K, MARTON MJ, WITTEVEEN AT, SCHREIBER GJ, KERKHOVEN RM, ROBERTS C, LINSLEY PS, BERNARDS R, FRIEND $\mathrm{SH}$ (2002). Gene expression profiling predicts clinical outcome of breast cancer. Nature 415: 530-536.

VAN VAERENBERGH I, FATEMI HM, BLOCKEEL C, VAN LOMMEL L, IN'T VELD P, SCHUITF, KOLIBIANAKISEM, DEVROEYP, BOURGAINC (2011). Progesterone rise on $\mathrm{HCG}$ day in $\mathrm{GnRH}$ antagonist//FSH stimulated cycles affects endometrial gene expression. Reprod Biomed Online 22: 263-271. 
VAN VAERENBERGH, MCINTIRE R, VAN LOMMEL L, DEVROEY P, GIUDICE L, BOURGAIN C (2010). Gene expression during successful implantation in a natural cycle. Fertil Steril 93: 268.e15-268.e18.

VIDAL M, CUSICK ME, BARABÁSI AL (2011). Interactome networks and human disease. Cell 144: 986-98.

WANG Z, GERSTEIN M, AND SNYDER M (2009). RNA-Seq: a revolutionary tool for transcriptomics. Nat Rev Genet 10: 57-63.

WILCOXAJ, BAIRD DD, WEINBERG CR (1999). Time of implantation of the conceptus and loss of pregnancy. N Engl J Med 340: 1796-1799.

YANAIHARA A, OTSUKA Y, IWASAKI S, AIDA T, TACHIKAWA T, IRIE T, OKAI T (2005). Differences in gene expression in the proliferative human endometrium. Fertil Steril 83: 1206-1215. 


\section{Further Related Reading, published previously in the Int. J. Dev. Biol.}

Endometrial responses to embryonic signals in the primate

Prajna Banerjee and Asgerally T. Fazleabas

Int. J. Dev. Biol. (2010) 54: 295-302

http://www.intjdevbiol.com/web/paper/082829pb

Local regulation of implantation at the human fetal-maternal interface

Evdokia Dimitriadis, Guiying Nie, Natalie J. Hannan, Premila Paiva and Lois A. Salamonsen Int. J. Dev. Biol. (2010) 54: 313-322

http://www.intjdevbiol.com/web/paper/082772ed

Knowledge-based bioinformatics for the study of mammalian oocytes

Francesca Mulas, Lucia Sacchi, Lan Zagar, Silvia Garagna, Maurizio Zuccotti, Blaz Zupan and Riccardo Bellazzi

Int. J. Dev. Biol. (2012) 56: 859-866

http://www.intjdevbiol.com/web/paper/120138fm

Signaling pathways dictating pluripotency in embryonic stem cells Debasree Dutta

Int. J. Dev. Biol. 57: 667 - 675 (2013)

\section{Understanding the regulatory genome}

M. Eva Alonso, Bárbara Pernaute, Miguel Crespo, José Luis Gómez-Skarmeta and Miguel Manzanares

Int. J. Dev. Biol. 53: 1367 - 1378 (2009)

5 yr ISI Impact Factor $(2011)=2.959$
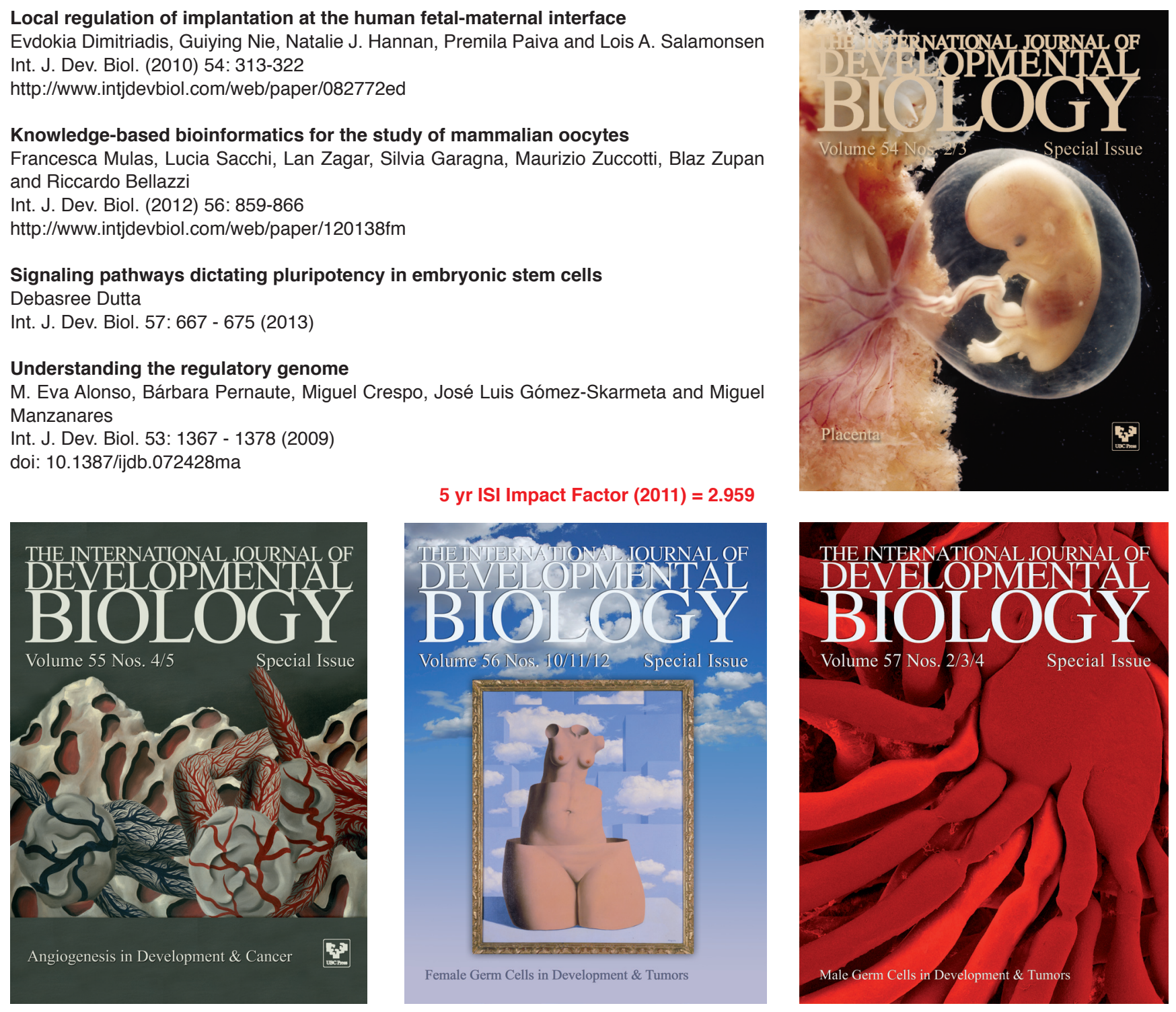